IZA DP No. 5607

\title{
Revealed Informal Activity
}

Ralitza Dimova

Ira N. Gang

John Landon-Lane

March 2011 


\title{
Revealed Informal Activity
}

\author{
Ralitza Dimova \\ University of Manchester \\ and IZA \\ Ira N. Gang \\ Rutgers University \\ and IZA

\section{John Landon-Lane} \\ Rutgers University
}

\section{Discussion Paper No. 5607 \\ March 2011}

IZA

P.O. Box 7240

53072 Bonn

Germany

Phone: +49-228-3894-0

Fax: +49-228-3894-180

E-mail: iza@iza.org

\begin{abstract}
Any opinions expressed here are those of the author(s) and not those of IZA. Research published in this series may include views on policy, but the institute itself takes no institutional policy positions.

The Institute for the Study of Labor (IZA) in Bonn is a local and virtual international research center and a place of communication between science, politics and business. IZA is an independent nonprofit organization supported by Deutsche Post Foundation. The center is associated with the University of Bonn and offers a stimulating research environment through its international network, workshops and conferences, data service, project support, research visits and doctoral program. IZA engages in (i) original and internationally competitive research in all fields of labor economics, (ii) development of policy concepts, and (iii) dissemination of research results and concepts to the interested public.
\end{abstract}

IZA Discussion Papers often represent preliminary work and are circulated to encourage discussion. Citation of such a paper should account for its provisional character. A revised version may be available directly from the author. 
IZA Discussion Paper No. 5607

March 2011

\section{ABSTRACT}

\section{Revealed Informal Activity}

What does it mean to be in the informal sector? Many characterizations have been used in the literature, for example, firms that are unregistered or employ a small workforce or firms/economic enterprises that do not have access to formal capital markets. But many people participate in both formal and informal activities, while classification of participation is often based on primary employment. This creates limitations to the analytical power of existing measures of informality. We develop a method for assigning households to the informal sector by inferring informal sector activity using income and expenditure surveys. We apply this method to the case of Bulgaria using LSMS income and expenditure surveys before and after a significant economic reform and compare it to those made using other indicators of informal sector activity. Our work shows that the informal sector acts as a buffer for households during periods of crisis when formal sector employment opportunities are limited. It shows the limitations of alternative stylized measures of informality in assessing the vulnerability of households involved in the informal sector, especially during periods of extreme economic hardship.

JEL Classification: $\quad 017$

Keywords: $\quad$ informal labour markets, crisis, Bulgaria

Corresponding author:

Ralitza Dimova

School of Environment and Development

University of Manchester

Arthur Lewis Building-1.073

Manchester M13 9PL

United Kingdom

E-mail: ralitza.dimova@manchester.ac.uk 


\section{Revealed informal activity}

In order to perform economic analysis on the effectiveness of policies aimed at those individuals who derive income from informal sector activity we first need to have accurate measurements of informal sector activity. If we are to perform economic analysis at a disaggregated level we also need to be able to allocate households (or individuals) into the informal sector. ${ }^{1}$ Here the biggest hurdle to formal economic analysis is that the informal sector is hard to define and hard to measure. The difficulty in measuring the informal sector makes it difficult to say anything economically concrete about the nature of the informal sector and its participants. We define a new procedure which, using existing data sets, will allow us to statistically measure the informal sector. With this new method in hand we will then be able to make formal inferences about the informal sector and its participants, analyze the economic forces that drive the movement into and out of the informal sector and discuss economic policies aimed at helping those individuals participating in the informal sector.

A major open question in the informal sector literature is the definition of what it means to be in the informal sector. While there seems to be a consensus on the broad concept of informality, namely "economic units with scarce or no capital, using primitive technologies and unskilled labor [..] low productivity"...."not complying with norms in terms of labor contracts, taxes and labor regulations" (ILO, 1991; ILO, 2002), the measurement of these characteristics have posed enormous hurdles to both researchers and policy makers. Clearly, the productivity of informal activities is difficult to measure and compare, while differences in legal frameworks both related to registration of small enterprises and labor regulations makes it difficult to construct comparable informality indicators on the basis of legal compliance.

The literature has therefore adopted shortcuts in defining informality on the basis for instance of the type of unit of employment, especially its size, or the type of job, such as work without labor protection. However, the mainstream selfemployment literature (e.g. Lucas, 1978; Jovanovic, 1982; and Evans and Leighton, 1989) indicates that entry into self-employment should typically be seen as a vocational choice in line with a worker's comparative advantage, although one with

\footnotetext{
${ }^{1}$ Later we discuss the use of household vs. individual observations.
} 
irregular relations with the state. If this is indeed the case, informality defined solely on the basis of firm size may create a misplaced perception of the vulnerability or low productivity status of informal activities. Indeed, research on small and medium enterprises in developing countries often reveals them as drivers of creative destruction and growth, as opposed to participants in unproductive activities at the outskirts of the economy (Tybout, 2000). Registration as a further refinement of the measure is not very helpful in this respect either, given the different requirements for business registration across countries. Nor is the definition of unskilled labor involved in informal activities, given that many highly entrepreneurial jobs do not require higher levels of education, while people with even tertiary education often get involved in secondary employment in the informal sector.

Another issue in dealing with the informal sector is that many people may participate in both formal and informal activities (e.g. doctors and taxi drivers may participate in both formal and informal activities). Many apparently unemployed people or people out of the labor force may be involved in informal activities, while numerous examples can be given of informal workers working for formal enterprises. All these problems suggest that a new method of inferring informal activity is needed.

We adopt a broad and flexible definition of informality that goes beyond managing a small firm or working without formal labor contract. It encompasses any effort undertaken to enhance one's living standard beyond reported income. We believe that this measure captures the broad spirit of the concept of informality, while avoiding many of the shortcomings of stylized shortcuts in its definition.

Our novel approach uses household information about income and expenditure to allocate households (or individuals) to the informal sector. We argue that households that spend considerably more than their total income must be getting income from informal sources. In this context, total income is the sum of labor income, transfers, and the change in asset position. If after accounting for all of these sources of income there is still a large difference in announced income and announced expenditure then we argue that the household is participating in the informal sector. In consuming goods and services in amounts far in excess of what its measured income would suggest, the household (or individual) has "revealed" itself to be participating in the informal sector.

Key to our method is the use of income and expenditures accounts to assign households to the informal sector. The income and expenditures accounts available in 
the Living Standards Measurement Survey (LSMS) ${ }^{2}$ data sets provide a good basis for such an exercise as they incorporate all relevant information on the flow of resources in and out of the household. Specifically, the expenditure accounts incorporate data on all expenditures including durable goods, while the income accounts contain data on both labor and non-labor incomes, including the net incomes from agricultural production and consumption, remittances and savings. With the income and expenditure accounts devised in such a way, total expenditures should equal total incomes.

Our main idea is to assign any household with significant excess of expenditures over incomes to participation in informal sector activities. Clearly, this definition of informal activity is quite broad but one of the purposes of this paper is to compare our approach of measuring the informal sector with other approaches. Once this is carefully done we will be able to give guidance to practitioners as to what threshold values to use so that the informal sector activity that we identify accords with accepted definitions of the informal sector. The elegance in this approach is that we have a deterministic method to infer informal sector activity from established cross-sectional, longitudinal and panel data sets that will allow economic researches to bring all their established tools to bear on important questions regarding the informal sector.

Up to now our discussion has focused on whether the household was involved in informal sector activity, without addressing which person in the household may have been directly involved in the informal sector. The household is generally the appropriate unit of analysis, as expenditure is difficult to assign to any one individual. While the source of formal sector income can often be assigned to an individual, in keeping with our idea of the informal sector, informal income cannot. For example, the formal sector employee may have a second informal sector job; an apparently non-working member of the household may in fact be employed in the informal sector; or children may be participating in the informal sector. While we are able to easily assign households to the informal sector, the data requirements for assigning informal sector income to particular persons in that household are much more stringent. It may be possible to employ time use data, when available, to allocate informal sector activity to individuals.

\footnotetext{
${ }^{2}$ http://go.worldbank.org/IPLXWMCNJ0
} 


\section{The Informal Sector during Crisis: The Case of Bulgaria}

We use data from Bulgaria to apply our measure of revealed informal activity. During the period of study Bulgaria underwent significant economic change which will allow us to see how our measure of informal activity compares to the other methods of measuring informal sector activity. We will also be able to study how informal sector activity adjusts to changing economic conditions, especially in times of severe economic stress.

During the first half of the 1990s Bulgaria experienced significant output loss and rising inflation, much more than in most other Central and East European (CEE) countries. Whereas the CEE economies that joined the European Union (EU) in 2004 reached the trough of their output loss in 1991-92 and were able to contain inflation by 1993, Bulgaria's GDP continued to fall through 1993, while hyperinflation was witnessed as late as 1997. This lackluster performance relative to most other CEE countries was largely a result of the absence of reform until the financial crisis of 1996-97.

Reforms were initiated in earnest only after the financial crisis, and they included rapid privatization, reform of the pension and social-welfare structure, and the establishment of a currency board. One of the immediate outcomes of this programme was the transfer of most of Bulgaria's productive resources from public into private hands, such that by the end of the 1990s, the private sector accounted for nearly 70 per cent of the country's GDP (National Statistical Institute 2003; Bulgarian Privatization Agency 2000). In the process, official employment declined at the rate of about 2 per cent per annum and as late as 2001 the unemployment rate was as high as 17.3 per cent, with 62 per cent of the unemployed people remaining unemployed for more than a year. At the same time the unemployment benefit system in Bulgaria remained among of the least generous in Europe (Garibaldi, Makovec and Stoyanova 2001).

The crisis of 1996-97 contributed to not only rapid restructuring and labour shedding, but also to a significant real wage decline, such that by 1997 the average real wage in Bulgaria was 61.1 per cent lower than its 1990 level (Rutkowski 2003). Besides earnings, hyperinflation also eroded savings; indeed much more than in other transition economies in CEE (Rutkowski 1999; IMF 2002). All of these contributed to a 77 per cent increase in poverty in the 1995-97 period (Sahn et al. 2002). 
It is interesting to note that despite the low level of unemployment benefits, one of the highest unemployment rates in CEE, and high correlation between unemployment and poverty, reservation wages in Bulgaria remained high throughout the transition period (Rutkowski 1999). This observation, together with the extraordinarily high discouragement rate among unemployed males indicates that a high proportion of the Bulgarian population might have found its way towards the informal economy (Garibaldi et al. 2001). The plausibility of this proposition is further augmented by the extraordinary payroll tax burden in transition Bulgaria, accumulating into a 41 per cent tax wedge between labour costs to employer and take home earnings, as well as by an excessively restrictive business environment leading to a lower number of officially registered Small and Medium Enterprises (SME) than elsewhere in CEE. According to existing macroeconomic estimates, the informal economy in Bulgaria accounts for at least a fourth of the country's GDP (Nenovski and Hristov 2000).

\section{Data and details on the measurement of informal activity}

The data used for our empirical analysis on Bulgaria is part of the Living Standards Measurement Surveys (LSMS), provided by the World Bank. The surveys provide detailed information on employment, income, consumption, education and demographic characteristics for all members of about 2500 households in 1995, 1997 and 2001. The surveys are repeated cross-sections and a small panel can be created only for part of the households available in both 1995 and 1997. In this study we only use the cross-sectional elements of each of the surveys.

As indicated earlier, we focus on the revealed informal activity of individuals and households by assigning to the informal sectors those households with reported incomes that systematically fall short of their reported expenditures. The income and expenditures accounts available in the LSMS data sets provide a good basis for such an exercise as they incorporate all relevant information on the flow of resources in and out of the household. The expenditure accounts incorporate data on all expenditures including durable goods, while the income accounts contain data on both labor and non-labor incomes, including the net incomes from agricultural production and consumption, remittances and savings. Moreover, the Bulgarian LSMS data allows us to directly account for changes in assets, including livestock and food 
inventories. With the income and expenditure accounts devised such, total expenditures should equal total incomes. That expenditures can greatly exceed incomes in the data indicates participation in informal sector activities.

In order to avoid the possibility of a systematic statistical error affecting our exercise, we use as a point of departure a reference household of which we are sure that it belongs to the formal sector. We select households consisting of married couples $^{3}$, where both the head and spouse are of working age ${ }^{4}$, work on a term-less contract and a 40-hour week schedule, neither of them reports any second job or selfemployment activity and the household does not own a household business. We exclude from the sample households in which either spouse is pursuing higher studies at the time of the interview. For a sample of these households we calculate the median seasonally deflated expenditures and incomes for both 1995 and 2001 and then take the ratio of the two. Our results indicate that the ratio of expenditures to incomes is 1.096581 in 1995 and 1.089261 in 2001 . In other words, on average, for our reference category of a formal sector household defined in a rather conservative way, total expenditures are approximately equal to total incomes.

Figure 1 highlights the discrepancies between the logarithm of incomes and expenditures for the reference households and compares these discrepancies with those of the total samples for 1995 and 2001. We observe that the overlap between incomes and expenditures is significantly more even for the reference categories than the total sample and assign this difference to the impact of the informal sector.

While the ratio of the median expenditures and incomes for the reference household is approximately 1 , we prefer to rely on a significantly stricter measure of the informal sector and assign to the informal sector any household for which expenditures exceed income by 100 per cent $^{5}$. Our rationale is quite obvious; to fund this expenditure lifestyle, household must obtain income from somewhere. Borrowing was fairly primitive in Bulgaria at this time (and it is so in a large number of

\footnotetext{
${ }^{3}$ The households of single heads of households in Bulgaria are few and aside from family of divorced individuals, they typically are elderly (widowed) households.

${ }^{4}$ In Bulgaria in the 1990s this means 18-55 for women and 18-60 for men. This is based on the fact that 18 is the age of graduation from compulsory secondary education, while statutory retirement age was 55 for women and 60 for men.

${ }^{5}$ In our empirical analysis we experimented with alternative definitions, ranging from expenditure-income rations equal to 1.5 to ratios equal to 2.5 .
} 
developing countries) and our income measure already includes transfers, incomes from real estate, financial assets and changes in asset positions.

We also compare our measure of revealed informal activity with some stylized measures of informality. Specifically, we define three additional, fairly stylized informality measures. First, we define a dummy variable, taking the value of 1 if anyone in the household works without a contract and or formal labour protection. Secondly, we define a dummy variable, that takes the value of 1 if the household either operates a small business or anyone in the households works as own-account self-employed individual.

Figure 1: Distribution of total expenditures and incomes

1995: Whole Sample

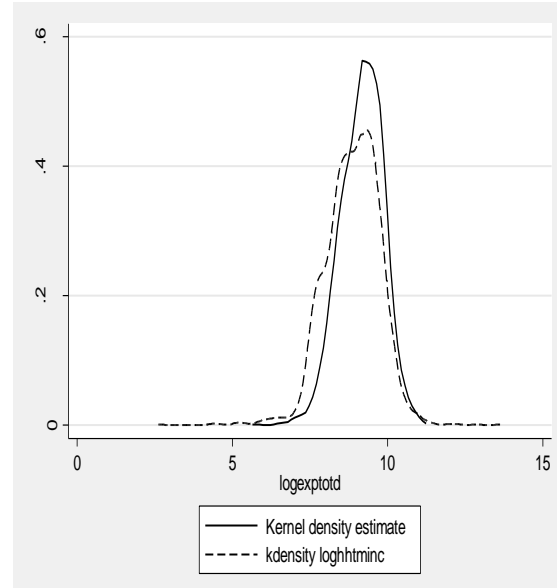

2001: Whole Sample
1995: Reference Household

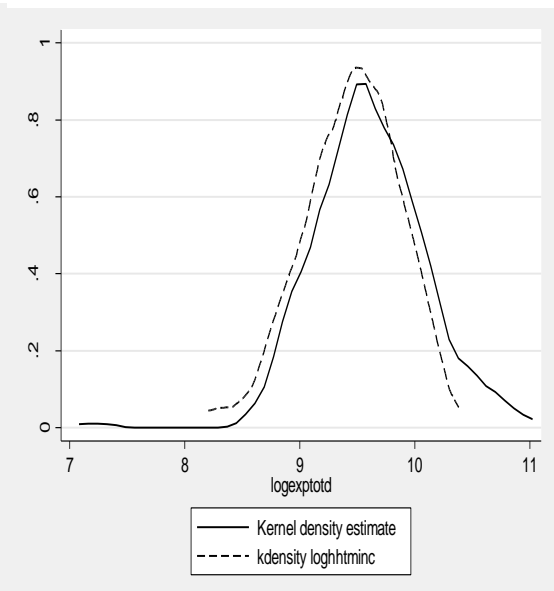

2001: Reference Household

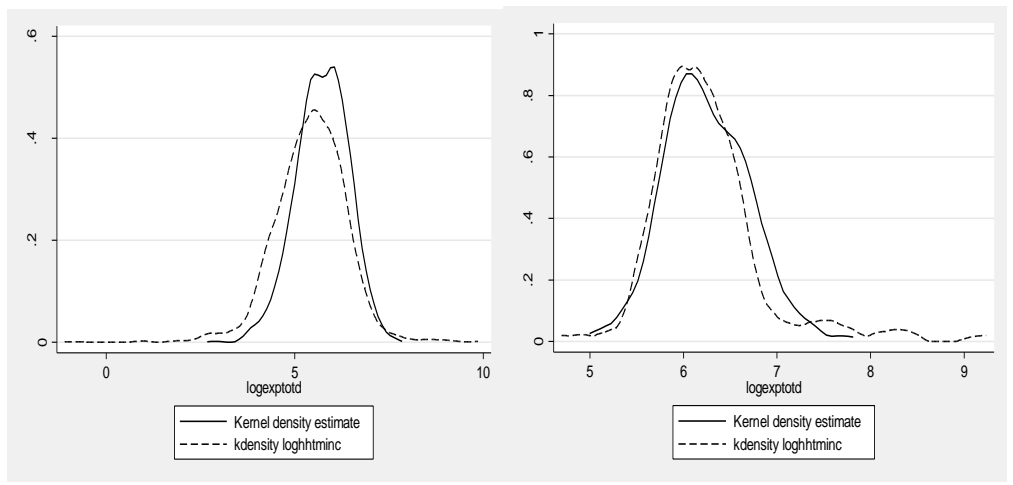


Table 1 reports the proportion of households with some informal activity using our approach to measuring informal activity and using other common approaches to measure informal sector activity. Two striking differences are apparent in Table 1. The first difference is in the relative sizes of the proportion of households participating in the informal sector. Our preferred measure of informal sector activity estimates that roughly one third of all Bulgarian households that were sampled in 1995 and 2001 participated in the informal sector. In 1997 the proportion of households with some informal sector activity more than doubled. This is in stark

Table 1: Proportions of Households participating in Informal Sector

\begin{tabular}{lccc} 
Measure of Informal Activity & 1995 & 1997 & 2001 \\
\hline \hline I1: Revealed Informal Activity & 0.354 & 0.745 & 0.385 \\
I2: Self-employment & 0.069 & 0.055 & 0.061 \\
I3: No worker protections & 0.064 & 0.043 & 0.071 \\
I4=I2 or I3 & 0.129 & 0.095 & 0.129
\end{tabular}

contrast to the other measures of informal sector activity. The other measures estimated the proportion of households participating in the informal sector to be much smaller with the combined measure reporting that only 10 percent of the households sampled had any informal sector activity.

The second glaring difference between our measure of revealed informal sector activity and the other measures is the behavior of the informal sector during the height of the Bulgarian economic crisis. Our measure of informal sector activity doubles during 1997 which is immediately after the worst of the Bulgarian economic crisis. The Bulgarian crisis of 1996-1997 led to massive layoffs and much lower real wages. Given this type of significant crisis it is expected that households react by augmenting their formal sector income with informal sector activity. Using the expenditure approach we do see that informal sector activity increases significantly during the crisis but falls back to pre-crisis levels by 2001 .

Using the other measures of informal activity such as self-employment and working in jobs that offer little employment protections we see the opposite behavior. 
These measures all show a decline in the informal sector during the period of the crisis. This highlights one of the weaknesses of these other measures in that they are employment based measures. In order to be assigned to the informal sector using these measures the household must first report that at least one member of the household is either self-employed or working in a job without employment protections. A household is not reported to be in the informal sector if they don't report working in one or they are laid off from their employment. During the crisis in

Table 2: Variables used in Probit Regressions

Variable Name Definition

$\begin{array}{ll}\text { Age_Hd } & \text { Age of head of household } \\ \text { AgeSq_Hd } & \text { Squared age of head of household } \\ \text { Married_Hd } & =1 \text { if head married } \\ \text { Female_Hd } & =1 \text { if head female } \\ \text { Ethnic_Hd } & =1 \text { if head member of ethnic minority } \\ \text { EdSec_Hd } & =1 \text { if head;s highest education is secondary education } \\ \text { EdVoc_Hd } & =1 \text { if head's highest education is vocational education } \\ \text { EdTer_Hd } & =1 \text { if head's highest education is University education } \\ \text { EdSec_Oth } & \text { Proportion of household with only secondary education } \\ \text { EdVoc_Oth } & \text { Proportion of household with vocational education } \\ \text { EdTer_Oth } & \text { Proportion of household with University education } \\ \text { Prop6 } & \text { Proportion of household under the age of } 6 \\ \text { Prop715 } & \text { Proportion of household between the ages of } 7 \text { and } 15 \\ \text { Propgt60 } & \text { Proportion of household over the age of } 60 \\ \text { HHsize } & \text { Size of Household } \\ \text { Urban } & =1 \text { if household lives in urban area. }\end{array}$

1996 and 1997 there was massive job destruction which could be one reason why the size for the informal sector fell for the 1997 sample.

\section{Who is in the informal sector?}

In order to investigate informal activity in more detail we now report marginal effects from simple Probit regression models with informal activity as the dependent variable. We use three different measures of informality, namely the measure of revealed informal activity, which indicates that household expenditures are at least twice as high as household incomes, a dummy variable indicating that the household 
is involved in small business activities and a dummy variable indicating that there is at least one household member who works without a labor contract and receives no labor protection. As explanatory variables, we use various household characteristics such as age of head and age squared to see if informal sector activity is non-linear in age of the head of household. We also include a gender variable to distinguish households whose heads are female from other households.

We include information on the educational attainment of the head and on the average educational attainment of the other members of the household. To do this we include dummy variables for an individual's highest qualification. The labor market literature on Bulgaria during the 1990s indicates that the type of education acquired has significant impact on the probability of individuals to obtain a job in the formal labor market (Dimova and Gang, 2007). Hence, we find it important to differentiate between types of education acquired: university, versus vocational, versus general secondary education, as opposed to the level of education acquired, captured by a number of years of education variable. Based on previous research, our assumption is that higher levels of education imply higher probability to enter the formal labor market and lower probability to enter the informal labor market. We also assume that the level of education of the household is more important in making these choices than the level of education of secondary household members (Grimm and Gunter, 2005). We also include variables that indicate whether the household contains children or pensioners and we include information on the location of the household and its overall size.

The results for our measure of revealed informal activity can be found in Table 3. The first result of consequence is that it appears that for 1997 there are few significant explanatory variables. This year is an important year for Bulgaria in that Bulgaria was undergoing a severe economic crisis and was starting a program of significant economic reforms. From Table 2 it is also clear that this year almost three quarters of the households in our sample had some form of informal sector activity. Given the extent of the crisis and the observation that almost all households were participating in the informal sector, it is not surprising that there are no clear patterns appearing from the Probit regressions.

For the other two years, 1995 and 2001, the results are much clearer. In these years only about a third of all households had some form of informal sector participation and the pattern of results for these two years are quite similar. The Probit 
regressions indicate that there is significantly more informal sector activity in rural areas than in urban areas. To see whether there are significant differences in the nature of informal activities across rural and urban areas, we estimate separate regressions also for the sample of urban households.

In 1995 households whose heads are married are less likely to have informal sector activity. This is not the case in 2001. One reason for this might be than in 1995 the public sector was large and that there was a bias towards older (and hence more likely to be married) employees during this time. In 2001 the economic reforms had taken effect with a much smaller public sector and a much larger private sector which did not have the bias towards married employees ( Dimova, Gang, and Landon-Lane, 2006).

Another interesting result is that, while not completely consistent across 1995 and 2001, education has a negative marginal effect on the probability of participating in the informal sector. In 2001 the result is much stronger with both education

Table 3: Marginal effects: revealed informal activity 1995 1997

2001

\begin{tabular}{lcccccc} 
Variable & Full & Urban & Full & Urban & Full & Urban \\
\hline Age_Hd & -0.006 & - & -0.000 & 0.000 & - & - \\
& & $0.015^{* * *}$ & & & $0.012^{* * *}$ & $0.015^{* * *}$ \\
AgeSq_Hd & -0.005 & $0.092^{*}$ & -0.000 & -0.000 & $0.076^{*}$ & $0.095^{*}$ \\
Married_Hd & - & - & -0.030 & -0.055 & -0.030 & -0.035 \\
& $0.118^{* * *}$ & $0.154^{* * *}$ & & & & \\
Female_Hd & $0.060^{*}$ & 0.061 & 0.010 & 0.020 & $0.053^{*}$ & 0.045 \\
Ethnic_Hd & 0.046 & -0.005 & -0.010 & -0.065 & $0.185^{* * *}$ & $0.139^{* * *}$ \\
EdSec_Hd & $-0.003^{*}$ & 0.007 & 0.018 & 0.015 & -0.029 & $-0.064^{*}$ \\
EdVoc_Hd & -0.010 & -0.001 & -0.021 & -0.004 & -0.036 & $-0.057^{*}$ \\
EdTer_Hd & $-0.004^{*}$ & 0.004 & 0.033 & 0.044 & -0.038 & $-0.071^{*}$ \\
EdSec_Oth & $-0.168^{* *}$ & -0.010 & -0.066 & -0.087 & -0.088 & $-0.157^{* *}$ \\
EdVoc_Oth & $-0.158^{* *}$ & -0.092 & -0.074 & -0.118 & $-0.120^{*}$ & $-0.166^{* *}$ \\
EdTer_Oth & - & $-0.202^{* *}$ & -0.052 & -0.073 & $-0.193 * *$ & $-0.201 * *$ \\
& $0.267 * * *$ & & & & \\
Prop6 & -0.041 & $-0.231 *$ & $0.194 *$ & $0.293^{*}$ & -0.179 & $-0.277^{* *}$ \\
Prop715 & 0.008 & 0.011 & 0.129 & 0.045 & $0.186^{* *}$ & 0.058 \\
Propgt60 & -0.027 & -0.065 & 0.063 & 0.081 & - & $-0.111^{* *}$ \\
& & & & & $0.153^{* * *}$ & \\
HHsize & 0.009 & 0.011 & 0.013 & $0.035^{* * *}$ & 0.013 & $0.022^{*}$ \\
Urban & - & & - & & - & \\
& $0.161 * * *$ & & $0.116^{* * *}$ & & $0.076^{* * *}$ & \\
\hline Sample & 2462 & 1644 & 2323 & 1556 & 2633 & 1756 \\
Pseudo-R & 0.059 & 0.056 & 0.031 & 0.025 & 0.082 & 0.068
\end{tabular}


variables for the head and for the other members of the household being significant and negative for the urban sample. In the 1995 regressions, the negative impact of education is stronger in the full sample and weaker in the urban sample. This change from 1995 could be due to the economic reforms encouraging a private economy where education in the formal urban sector is more rewarded than in the previous socialist regime.

The age variables are also significant, especially in the urban sample, with the probability of informal sector activity declining at a decreasing rate with the age of the head of the household. Thus as the head of the household gets older it appears that they are more likely to find formal full time employment. During the period of the crisis in 1997 there is no age effect but this is rather understandable as all households were affected by the crisis.

The makeup of the household also has some affect on informal sector activity. While gender does not play a strong role in the results we observe that households with children under the age of 6 are less likely to have informal sector activity during the years 1995 and 2001 which might reflect the fact that members of the family that otherwise participate in the informal sector refrain from this when they have young children. During the crisis however families with young children were more likely to participate in informal sector activity, possibly as a matter of last resort at a time of extreme strain.

In 2001 households whose head were members of an ethnic minority were more likely to have informal sector activity. This result is not present in any of the other periods. One reason for this is that in 1995 the economy was still transitioning from a socialist economy where there were less discrimination in employment practices than in the private sector oriented economy of 2001.

The results from the Probit analysis for our measure of revealed informal activity, while not exhaustive, do appear to be reasonable in that the explanatory variables have in general the appropriate sign. It would now be interesting to compare these results with those based on the other two (stylized) definitions of informality.

Table 4 reports the marginal effects from our Probit regression results using the measure of informal activity that uses the availability of labour contract and protection as a measure of informality. These results are broadly consistent with those on revealed informal activity in that in the relatively normal years 1995 and 2001 tertiary education of other household members has a negative impact on the 
Table 4: Marginal effects: no labour security

\begin{tabular}{lcccccc} 
& \multicolumn{2}{c}{1995} & \multicolumn{2}{c}{1997} & \multicolumn{2}{c}{2001} \\
Variable & Full & Urban & Full & Urban & Full & Urban \\
\hline Age_Hd & 0.002 & 0.001 & -0.000 & -0.001 & 0.001 & -0.000 \\
AgeSq_Hd & -0.000 & -0.000 & 0.000 & 0.000 & -0.001 & -0.000 \\
Married_Hd & 0.005 & 0.019 & 0.011 & 0.018 & $-0.028^{* *}$ & -0.018 \\
Female_Hd & 0.006 & 0.019 & 0.019 & 0.025 & 0.001 & 0.015 \\
Ethnic_Hd & 0.013 & 0.033 & $0.027 *$ & 0.006 & $0.052^{* * *}$ & $0.049 * *$ \\
EdSec_Hd & 0.016 & 0.019 & -0.012 & -0.008 & -0.000 & 0.019 \\
EdVoc_Hd & -0.011 & -0.009 & -0.002 & -0.002 & $0.019^{*}$ & $0.032^{* *}$ \\
EdTer_Hd & -0.019 & -0.022 & -0.002 & -0.004 & -0.001 & 0.012 \\
EdSec_Oth & 0.019 & 0.028 & 0.012 & -0.017 & $0.050^{*}$ & 0.046 \\
EdVoc_Oth & 0.035 & $0.056^{*}$ & $0.035^{*}$ & -0.023 & $0.055^{* *}$ & 0.039 \\
EdTer_Oth & $-0.114 * *$ & $-0.090^{*}$ & -0.014 & -0.033 & $-0.075^{*}$ & $-0.072^{*}$ \\
Prop6 & 0.052 & 0.078 & -0.007 & -0.016 & -0.027 & -0.068 \\
Prop715 & $-0.066^{* *}$ & $-0.080^{*}$ & -0.034 & $-0.095 * *$ & -0.046 & -0.056 \\
Propgt60 & -0.030 & -0.018 & $-0.048^{* *}$ & -0.035 & $-0.052^{* *}$ & $-0.058^{* *}$ \\
HHsize & $0.009^{* *}$ & $0.010^{* *}$ & $0.005^{*}$ & $0.009^{* *}$ & $0.013^{* * *}$ & $0.018^{* * *}$ \\
Urban & -0.001 & & 0.001 & & -0.009 & \\
\hline Sample & 2462 & 1644 & 2323 & 1556 & 2633 & 1756 \\
Pseudo-R & 0.107 & 0.119 & 0.074 & 0.049 & 0.112 & 0.115
\end{tabular}

households participation in informal activities. Interestingly, the vocational education of both the household head and other household members has a positive impact on participation in informal activities, possibly on account of the obsolescence of these types of skills in the changing labor market. Finally, as in the case of revealed informal activities, belonging to an ethnic minority group, once again has a positive impact on the probability to participate in the informal sector.

While there are similarities between the results on informality measured as revealed informal activity and informality based on the labor contract measure of informal activities, the results on informality as self-employment/small business activity stand in stark contrast with those based on the other two measures. Most importantly, the Probit results reported in Table 5 indicate that during all years, including the crisis year 1997, higher levels of education are positively correlated with the probability to run a small enterprise or be (own account) self-employed. In this way, the results on the probability to be self-employed or small business manager reveal the small enterprise sector in Bulgaria as one more akin to dynamic entrepreneurship than one of shadow activities and once again confirm the need of using alternative measures when trying to assess the characteristics and fate of those involved in the informal economy. 
Table 5.: Marginal effects: self-employed/small business

\begin{tabular}{lcccccc} 
& \multicolumn{2}{c}{1995} & \multicolumn{2}{c}{1997} & \multicolumn{2}{c}{2001} \\
Variable & Full & Urban & Full & Urban & Full & Urban \\
\hline Age_Hd & 0.001 & $0.005^{*}$ & 0.004 & $0.006^{*}$ & 0.000 & 0.002 \\
AgeSq_Hd & -0.000 & $-0.000^{*}$ & $-0.000^{*}$ & $-0.000^{*}$ & -0.000 & -0.000 \\
Married_Hd & -0.017 & -0.014 & -0.016 & -0.002 & 0.004 & 0.015 \\
Female_Hd & -0.024 & -0.015 & -0.005 & -0.001 & $-0.025^{* *}$ & -0.024 \\
Ethnic_Hd & $-0.028^{*}$ & -0.022 & -0.013 & -0.023 & -0.009 & 0.004 \\
EdSec_Hd & 0.029 & $0.046^{*}$ & -0.008 & -0.015 & $0.027^{*}$ & $0.044^{*}$ \\
EdVoc_Hd & 0.011 & 0.014 & 0.003 & -0.004 & $0.034^{* * *}$ & $0.047^{* * *}$ \\
EdTer_Hd & $0.064 * * *$ & $0.073^{* * *}$ & 0.004 & -0.006 & $0.034^{* * *}$ & $0.049^{* * *}$ \\
EdSec_Oth & 0.005 & 0.006 & $0.076^{* * *}$ & $0.086^{* *}$ & 0.035 & 0.035 \\
EdVoc_Oth & -0.002 & -0.007 & $0.038^{*}$ & 0.048 & 0.027 & 0.028 \\
EdTer_Oth & 0.013 & 0.003 & $0.105^{* * *}$ & $0.136^{* * *}$ & $0.102^{* * *}$ & $0.138^{* * *}$ \\
Prop6 & -0.080 & -0.002 & -0.001 & 0.055 & 0.044 & 0.058 \\
Prop715 & -0.007 & -0.004 & 0.029 & $0.085^{*}$ & 0.024 & 0.041 \\
Propgt60 & -0.019 & -0.012 & -0.013 & -0.019 & - & $-0.054^{*}$ \\
& & & & & $0.052^{* * *}$ & \\
HHsize & $0.016 * * *$ & $0.010^{*}$ & $0.006^{* *}$ & 0.001 & $0.007 * * *$ & $0.012^{* * *}$ \\
Urban & -0.010 & & 0.003 & & 0.009 & \\
\hline \hline Sample & 2462 & 1644 & 2323 & 1556 & 2633 & 1756 \\
Pseudo-R & 0.056 & 0.060 & 0.099 & 0.071 & 0.148 & 0.127
\end{tabular}

\section{Discussion and Conclusions}

We outline a method to infer informal sector activity using income and expenditure surveys. We apply this method to the case of Bulgaria before and after a significant economic reform and investigate the effects of economic crisis on informal sector activity. We find that the informal sector acts, in part, as a buffer for households during periods of crisis when formal sector employment opportunities are limited. In this sense the presence of an informal sector provides a "safety net" and is welfare improving.

Our method is flexible enough to include all types of informal activities and unlike alternative fairly stylized measures of informality, it does not require us to define ex-ante what informality means. We argue that our measure is therefore superior to measures based on types of units of employment and types of jobs, as these measures are difficult to compare across countries and omit situations such as simultaneous participation in formal and informal activities, as well as situations where apparently non-working people are involved in informal activities. 
We use household information about income and expenditure to allocate individuals to the informal sector. We argue that households that spend considerably more than their total income must be receiving income from informal sources. In this context total income is defined to be the sum of labor income, transfers, and the change in asset position. If after accounting for all of these sources of income, and assuring that our variables are not fraught with measurement errors, there is still a large difference in announced income and announced expenditure then we argue that the household is participating in the informal sector.

The main objective of this study is to develop a deterministic method to assign households to the informal sector. Once we do this we can exploit the other information that is available for these households in formal econometric models. While this paper specifically ask about who was in the informal sector and its correlates before, during and after economic crisis, with informality defined and simply captured, questions can be addressed about the role that the informal sector plays in the economy, as well as gain insight into what are the important determinants of a household's (or individual's) involvement in the informal sector. 


\section{References}

Bulgarian Privatization Agency (2000). http://www.priv.government.bg/ap/bg/.

Dimova, R. and I. Gang (2007). Self-Selection and Earnings During Volatile Transition. Journal of Comparative Economics 35(3) 612-629.

Dimova, R., I. Gang, and J. Landon-Lane (2006). The Informal Sector during Crisis and Transition. in Guha-Khasnobis B. and R. Kanbur (eds) Informal Labour Markets and Development, pages 88-108, Palgrave-McMillan Press.

Evans, David and Leighton, Linda (1989). Some empirical aspects of entrepreneuriship. American Economic Review, 79(3), 519-535.

Garibaldi, P., M. Makovec and M. Stoyanova (2001). From Transition to Accession: The Bulgarian Labour Market over the 1990s. World Bank Technical Paper No. 494, World Bank: Washington, DC.

Grimm, M. and Günther, I. (2006). Inter and Intra-household linkages between the informal and formal sectors: a case study for urban Burkina Faso. GuhaKhasnobis B. and R. Kanbur (eds) Informal Labour Markets and Development, pages 88-108, Palgrave-McMillan Press.

International Monetary Fund (2002). Bulgaria. Recent Economic Developments and Statistical Appendix. IMF: Washington, DC.

ILO (1991). The Dilemma of the Informal Sector, International Labour Conference, Report of

the Director General.

ILO (2002). "Decent Work and the Informal Economy." Report VI for the 90th International Labour Conference, Geneva.

Jovanovic, B. (1982). The selection and evolution of industry. Econometrica, 50, 64970.

Lucas, R. (1978). On the size distribution of business firms, Bell Journal of Economics, 9, 508-23.

National Statistical Institute of Bulgaria (2003). http://www.nsi.bg/Index-e.html.

Nenovski, N. and K. Hristov (2000). Currency Circulation after Currency Board Introduction in Bulgaria. DP\l3\2000 Bulgarian National Bank.

Rutkowski, J. (1999). Labor Markets and Poverty in Bulgaria. SP Discussion Paper No. 9918. World Bank: Washington, DC. 
Rutkowski, J. (2003). Why is Unemployment so High in Bulgaria. World Bank Policy Research Working Paper No. 3017. World Bank: Washington, DC.

Sahn, D., S. Younger and C. Meyerhoefer (2002). Rural Poverty in Bulgaria: Characteristics and Trends. http://people.cornell.edu/pages/des16/ sahn/wp132.pdf.

Tybout, J. (2000). Manufacturing firms in developing countries: how well they do, and why? Journal of Economic Literature, 38, pp. 11-44. 